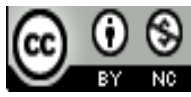 \\ Jurnal Terapan Manajemen dan Bisnis is licensed under \\ A Creative Commons Attribution-NonCommercial 4.0 International License.
}

\title{
Dominant Variables That Affect The Level of Profitability in Sharia Banks and Conventional Banks
}

\author{
Irawati Junaeni ${ }^{1)}$ \\ 1) Perbanas Institue, Indonesia \\ E-mail: ira.bwahyudi@gmail.com
}

\begin{abstract}
This study aims to analyze the dominant factors that affect profitability in the Sharia Commercial Bank and Conventional Bank Indonesia Year 2009-2014. The sample used in this study is 7 Sharia Commercial Banks and 10 Conventional Commercial Banks in Indonesia. The technic sample used in this study by purposive sampling method. This research uses panel data regression methods and estimation model used is a Random Effect Model. The result of research on sharia bank of internal factors concludes that BOPO variable has a significant influence on return on asset (ROA) and from external factors of BI Rate significant effect on return on asset (ROA). While conventional banks of internal factors conclude that BOPO and NPL variable have significant influence to return on asset (ROA) and from external factor conclude that BI Rate has a significant effect to return on asset ROA). In this research, BOPO variable has a more dominant influence on ROA than other variables.
\end{abstract}

Keywords: internal Tractors, External Tractors, ROA

\section{Introduction}

The economic crisis that occurred in 2008, where the crisis caused the global economic crisis, caused the banking institutions affected. The banking sector relies heavily on the national economic exchange rate because their transactions use foreign currencies (Wibowo and Syaichu, 2013). The existence of banks as channelling institutions and the storage of public funds has a strategic place. As stated in the Law of the Republic of Indonesia no . 10 of 1998 dated November 10, concerning banking, a bank is a business bank that collects funds from the public in the form of savings and distributes to the community in the form of credit and or other forms in order to improve the standard of living of the people (Kasmir, 2007: 23). In Indonesia, there are two types of banks: sharia bank and conventional bank. Both types of banks have similarities and differences in their implementation.

The positive performance also has an impact on sharia banking. Sharia banking market share of the national banking industry increased from $4.0 \%$ to $4.6 \%$ (LPPS, 2012 ). The growth rate of sharia banking assets increased compared to the growth of national assets. The role of good financial performance is needed. The good financial performance of banks is seen from the condition of banks of a healthy predicate that is influenced by the high level of bank profitability. Understanding profitability by Gitman and Zutter (2012) "These measures enable analysts to evaluate the firm's profits with respect to a given level of sales, a certain level of assets, or the owner's Investment". Profitability used in this research is Return On Assets (ROA). According to Gitman \& Zutter (2012), Return On Assets (ROA) measures the overall effectiveness of management in generating profits with its available assets. 


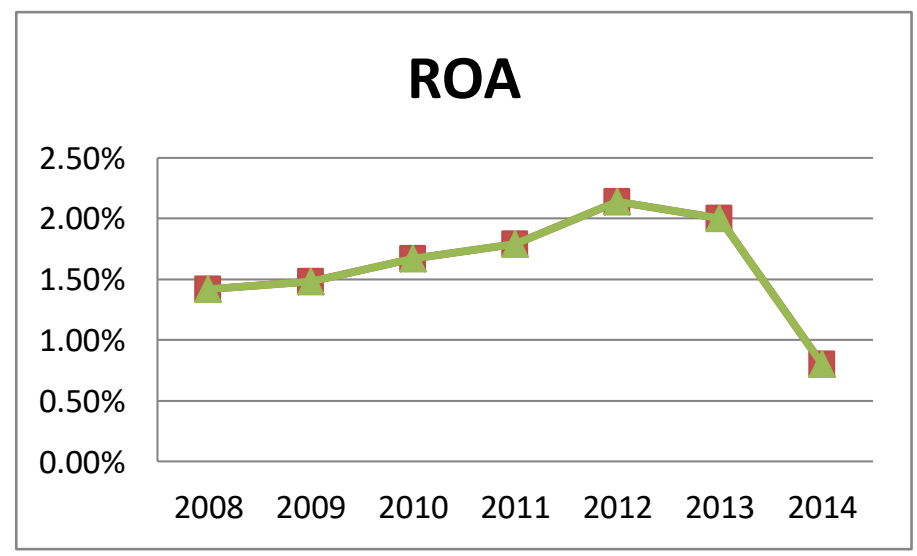

Source: Bank Indonesia (bi.go.id)

Fig. 1 The Development of Return On Assets of Sharia Commercial Banks (In Percentage)

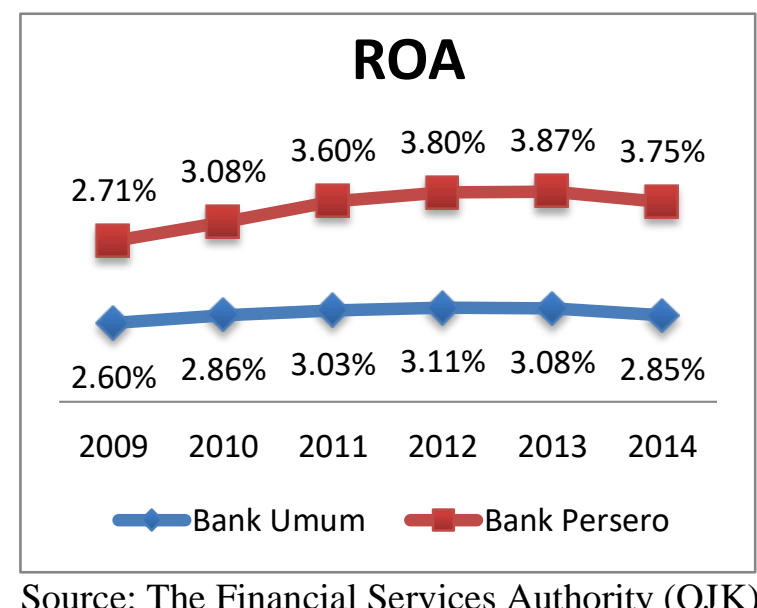

Fig. 2 Development of Return On Assets of Commercial Banks and Bank Persero (In Percentage)

Based on Fig. 1,2. In 2009 ROA of Commercial Bank of 2.60\%. In 2010 - 2012 ROA of Bank Persero increased to $2.86 \%, 3.03 \%$, and $3.11 \%$, then in $2013-2014$ ROA Commercial banks decreased to 3.08\% and 2.85\%. In 2009 ROA of Bank Persero was 2.71\%. In $2010-2013$ ROA of Bank Persero increased to 3.08\%, 3.60\%, 3.80\% and 3.87\%, then in 2014 ROA Bank Persero decreased to $3.75 \%$.

There are two factors that influence profitability that is an external factor and an internal factor. The first factor is an external factor, that is macro factors which does not have direct relations to bank profitability level but can influence financial condition in a country . External factors are used to make business decisions that can be taken to protect the various parties concerned, especially on the depositors and parties who used bank funds of Indonesia. External factors that can affect the financial condition, including the BI Rate, Inflation, and Exchange Rate. The BI rate is the monetary policy rate set by the Indonesian bank and announced to the public. The BI rate is the benchmark of interest rates on the money market including lending rates. The BI rate also affects bank profitability, as the BI rate increase will be followed by higher deposit and credit interest rates. (Luciana Spica and Utomo, 2006) The next variable is inflation. Inflation is defined as rising prices in general and 
continuing. An increase in the price of one or two items alone cannot be called inflation unless the increase extends (or causes price increases) to other goods (www bi.go.id). The exchange rate (exchange rate) is also one factor affecting the profitability level of a bank. In its development, one of the banking activities provides foreign-exchange sale and purchase services. The exchange rate difference is the profit generated from the foreign exchange customer. This happens because foreign exchange actors always offer to exchange rate. In that case the bank must pay attention to the exchange rate of the bank then the bank will get a profit in the form of fees and foreign exchange differences with the occurrence of fluctuations in exchange rates. Because of the income generated from transaction services in the form of fees and commissions earned, the bank also earns a very large income which actually comes from the exchange rate (Loen \& Ericsson 2008: 54).

According to (Hendrayanti \& Muharam, 2013) profitability (ROA) that can be influenced by internal factors that are micro factors that maintain the internal health of the bank because it has variables directly related to income obtained by banks and bank management. The bank's internal factor variables are used to measure how big the bank is to earn a profit, namely Operational Cost/Operating Income (BOPO), Loan to Deposit Ratio (LDR), Non-Performing Loan (NPL) and Third Party Fund (DPK). Operational Costs/Operating Income (BOPO) is operational risks that are heavily influenced by a number of deposits, deposited in banks in third-party funds derived from demand deposits, savings deposits and deposits, since deposits have an effect on interest expense and interest expense changes that reduce or decrease Increase the cost of BOPO so that it will affect the profitability of the bank. (Christiano et al, 2014) Liquidity risk is the ratio of LDR (loan to deposit ratio) is a ratio that shows the level of liquidity of a bank. Liquidity ratio is a risk faced by banks to meet the needs of its obligations and able to meet the provision of credit without any suspension (Eprima Dewi, et al, 2015). The amount of LDR standard given by Indonesian banks is $80 \%$ to $110 \%$, the higher the LDR ratio, the higher the ROA of a bank. This is because the provision of credit to customers can guarantee the bank's obligation to immediately meet the demand of customers that want to withdraw the money that has been used by the bank of disbursing loans provided with a larger total of third-party funds to increase interest income so that high-interest income will increase the profit And banks have performed well with the rising ROA of a bank. On the contrary, the lower the LDR ratio indicates that the bank is less effective against lending the credit. So it will lower the ROA in the bank. This is very suitable for the main function of the bank as an intermediary. If the LDR of a bank is below $80 \%$ then the funds disbursed are only equal to the LDR of the funds collected (Purwoko \& Sudiyatno, 2013). According to Iqbal (2012), the results of his research in Pakistan mentioned no effect of NPL on the level of profitability.

Based on the above description of the results of research on the level of bank income measured by profitability ratios (ROA) there are many variables that influence it. The authors classify the variables that can affect two groups, namely internal factors and external factors. Internal factors are factors that can be measured through banking performance, while external factors are factors that cannot be intervened by the management of banks nationally. Internal factors are BOPO, LDR, NPL and DPK while external factors are BI Rate, Inflation, US Dollar Exchange Rate to rupiah.

Urgency, Research The ever-improving development of banks of conventional commercial banks and Bank Sharia in Indonesia, see whether it is attractive to customers, investors and other institutions for the development of conventional banking in Indonesia. Therefore, there are several internal factors related to the level of profitability of conventional banks: BOPO operational risk, LDR liquidity risk, NPL financing risk and third-party funds that need attention to be used as research The author conducted a study of dominant 
variables that affect the level of profitability in sharia and conventional banks in Indonesia in 2009-2014.

\section{Method}

\section{Population and Sample}

In this study, Islamic Banking in Indonesia during the period 2009-2014 is the population of the sample determined to determine the effect of financing risk, liquidity risk and operational risk on the profitability of sharia banks. The sampling technique used in this research is purposive sampling, that is the technique of sampling with a certain consideration. Characteristics of companies used as samples of this study are:

1. The banking sector is included in the category of Sharia Commercial Banks in Indonesia.

2. Complete annual financial statements from 2009 to 2014 issued by sharia commercial banks of Indonesia.

Types and Data Sources

The type of data used in this study is secondary data. Data onto the form of financial ratios of sharia commercial banks and conventional banks, the results of the preparations of the financial statements of Sharia Commercial Banks and Conventional. Banks for the period 2009-2014 which have been audited and then published. Researchers use quarterly data onto 2009 to years 2014 .

Sample Research

Table 1 Research Sample Bank Sharia

\begin{tabular}{ll}
\hline No. & \multicolumn{1}{c}{ Bank Syariah } \\
\hline 1. & Bank Syariah Mandiri \\
2. & Bank Bukopin Syariah \\
3. & Bank Mega Syariah \\
4. & Bank Rakyat Indonesia Syariah \\
5. & Maybank Syariah \\
6. & Panin Bank Syariah \\
7. & Bank Muamalat Indonesia \\
\hline
\end{tabular}

Table 2 Research Sample Bank Konvensional

\begin{tabular}{cl}
\hline No. & \multicolumn{1}{c}{ Bank Konvensional } \\
\hline 1. & Bank Rakyat Indonesia \\
2. & Bank Mandiri \\
3. & Bank Central Asia \\
4. & Bank Negara Indonesia \\
5. & CIMB Niaga \\
6. & Bank Danamon \\
7. & Panin Bank \\
8. & Bank Permata \\
9. & Bank Tabungan Negara \\
10. & OCBC NISP \\
\hline
\end{tabular}

Method of collecting data 
Collection method used by nonparticipant observation, that is record or copy data which stated in Quarterly Public Financial Report of Sharia Public Bank and Conventional Bank.

Conceptual and Operational Variables

Table 3 Conceptual and Operational Variables

\begin{tabular}{lll}
\hline No & \multicolumn{1}{c}{ Variable } & \multicolumn{1}{c}{ Proxy } \\
\hline 1 & Profitability & ROA \\
2 & Non-Performing Financing/Non-Performing Loan & NPF/NPL \\
3 & Financing Deposit Ratio/Loan to Debt Ratio & FDR/LDR \\
4 & Comparison of operational costs with operating income & BOPO \\
5 & Third-Party Funds & DPK \\
6 & Inflation & INFLASI \\
7 & BI rate & BI rate \\
8 & Exchange rate & KURS \\
\hline
\end{tabular}

Data Analysis Techniques

This study uses panel data regression because the data used in the form of panel data which is a combination of cross section and time series data (Widarjono: 2013). This is because the object of this study consists of 7 sharia banks of Indonesia period 2009-2014 in quarterly forms. Research using the help of quantitative data processing software tools of the form of Microsoft excel 2007 and e views 80.

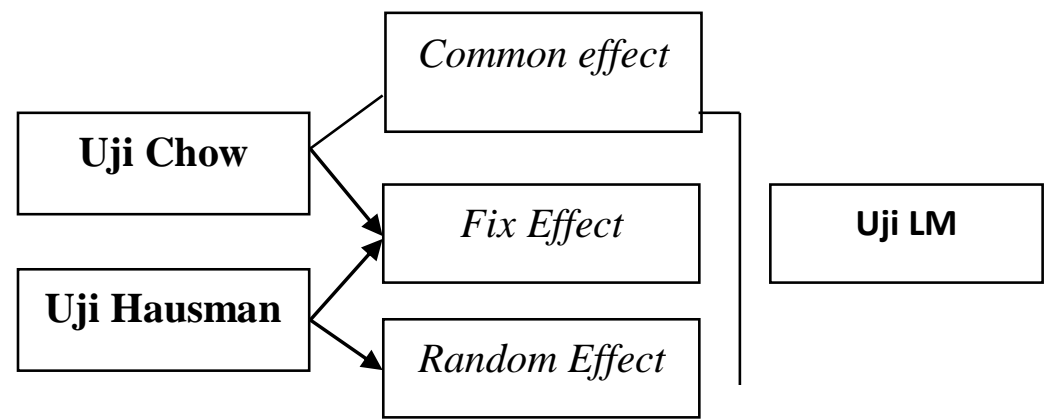

Fig. 1 Scheme for Testing of Selection of Panel Data Estimation Model

The results obtained in the three better tests are used, ie there are two tests that show the use of random or random effect method, while only one test using fixed-effect method. Therefore, the method of random or random effect is the best data regression estimation method of this study.

\section{Compare Results}

Results E Views of two regression data panels for conventional banks and sharia banks are compared. The higher coefficient results of the regression equation are a more dominant result than the lower coefficients.

\section{Discussion}

Sharia Commercial Bank

The equation of the regression model is as follows: 
ROA = 8.701987 + 5.25E-05 FDR - 0.041604 NPF - 0.055414 BOPO - 1.00E-15 DPK + 0.246134 INFLASI - 0.287522 BI RATE - 2.372349 KURS

Table 4 Internal Factors and External Factors of Sharia Commercial Banks

\begin{tabular}{ccccc}
\hline Variable & Coefficient & Std. Error & t-Statistic & Prob. \\
\hline INFLASI & -0.078435 & 0.085750 & -0.914695 & 0.3617 \\
BIRATE & -0.204655 & 0.104471 & -1.958969 & 0.0519 \\
KURS & 5560.184 & 13331.98 & 0.417056 & 0.6772 \\
NPF & -0.038048 & 0.047004 & -0.809458 & 0.4195 \\
FDR & -0.000220 & 0.001196 & -0.183604 & 0.8546 \\
DPK & $-8.75 \mathrm{E}-16$ & $6.57 \mathrm{E}-16$ & -1.331105 & 0.1850 \\
BOPO & -0.055610 & 0.002484 & -22.38860 & 0.0000 \\
C & 5.647697 & 4.869184 & 1.159886 & 0.2478 \\
\hline
\end{tabular}

Source: E views 8 Processing Results

Based on $\mathrm{t}$ test, BOPO, FDR, NPF, DPK, BI rate. Inflation and Exchange Rate on ROA in Sharia General Bank in Indonesia.

Operational Cost per Operating Income (BOPO)

Based on Test $t$ got the coefficient effect of -22.81130 with significance level of BOPO to $\mathrm{ROA}$ is 0.0000 with value sig $=0,000<0,05$. For $\mathrm{BOPO}$ variable have negative and significant effect of/on ROA at Sharia Commercial Bank in Indonesia period 2009-2014. So hypothesis 1a. that states BOPO negatively affected the ROA. Be accepted.

Financing to Deposit Ratio (FDR)

Based on Test $t$ got the effect of coefficient of 0.045041 with the level of significance of FDR variable to ROA is 0.9641 with significance level (sig) $=0.9641>0.05$. This shows that the FDR variable has a negative and insignificant effect on ROA. Thus, FDR has no effect on ROA in sharia commercial banks. Thus, hypothesizing $1 \mathrm{~b}$. which expresses FDR positively affects and signifies the ROA. Rejected.

Non Performing Financing (NPF)

Based on t-test, the effect of coefficient of - 0.922244 with the significance level of NPF to ROA is 0.3578 with a significance level ( $\mathrm{sig}$ ) $=0.3578>0.05$. It is shown that NPF variable has no effect on ROA. Thus, hypothesis 1c. which states NPF has a negative and significant effect on ROA. Rejected.

Third Party Funds (DPK)

Based on t-test, the effect of coefficient of - 1.567224 with a significance level of DPK variable to ROA is 0.1190 with a significance level $(\mathrm{sig})=0.1190>0,05$. This shows that the DPK variable has a positive and insignificant effect on ROA. Thus, the $1 \mathrm{~d}$. the hypothesis which states DPK has a positive and significant effect on ROA. Rejected.

BI Rate

Based on t-test, the effect of coefficient of -2.942409 with a significance level of BI Rate to ROA is 0.0037 with a significance level $(\mathrm{sig})=0.0037<0,05$. This shows that the variable BI Rate have negative and insignificant effect on ROA. Thus, the 1e hypothesis that the BI rates has a positive and significant effect on ROA. Rejected.

Inflation 
Based on Test $t$ got the effect of coefficient of 1.261954 with the level of significance of variable Inflation to ROA is 0.2088 with a significance level $(\mathrm{sig})=0.2088>0.05$. It is shown that the Inflation variable has a positive and insignificant effect on ROA. Thus, the $1 \mathrm{f}$ hypothesis that states Inflation has a positive and significant effect on ROA. Rejected.

\section{Exchange rate}

Based on t-test, the effect of coefficient of - 1.049445 with a significance level of the Exchange rate (Kurs) variable to ROA is 0.2956 with a significance level (sig) $=0.2956>0,05$. It is shown that the exchange rate variable has negative and insignificant effect of/on ROA. Thus, the 1g. hypothesis that states Exchange rate has a positive and significant effect on ROA. Rejected.

Based on the coefficient value on regression analysis of sharia bank is obtained $\mathrm{R}$ Square value influence BOPO, LDR, NPL. DPK Pirate, Inflation and Exchange Rate to ROA of 79.21\% showing the amount of contribution BOPO, LDR, NPL. DPK Pirate, Inflation and Exchange Rate to ROA.

Conventional Bank

The equation of the regression model is as follows:

$\mathrm{Y}=12,60684-0,099545$ BOPO-0,001389 LDR - 0,048354NPL + 0,003165 DPK + 0,163051 BIRATE - 0,022264 INFLASI - 0,811523 KURS

Table 5 Internal Factors and External Factors of Conventional Commercial Banks

\begin{tabular}{ccccc}
\hline Variable & Coefficient & Std. Error & t-Statistic & Prob. \\
\hline BOPO & -0.099545 & 0.006627 & -15.02173 & 0.0000 \\
LDR & -0.001389 & 0.002739 & -0.507101 & 0.6126 \\
NPL & -0.048354 & 0.010783 & -4.484053 & 0.0000 \\
DPK & 0.003165 & 0.003013 & 1.050514 & 0.2946 \\
BIRATE & 0.163051 & 0.058213 & 2.800938 & 0.0055 \\
INFLASI & -0.022264 & 0.034012 & -0.654605 & 0.5134 \\
KURS & -0.811523 & 0.583535 & -1.390702 & 0.1656 \\
C & 12.60684 & 1.991143 & 6.331459 & 0.0000 \\
\hline
\end{tabular}

Source: Eviews 8 Processing Results

Operational Cost per Operating Income (BOPO)

Based on Test $t$ got the effect of coefficient of - 15,02173 with level of significance of $\mathrm{BOPO}$ to ROA is 0.0000 with value sig $=0,000<0,05$. It is shown that $\mathrm{BOPO}$ has a negative and significant effect on ROA in Conventional Commercial Bank. For hypothesis 2a. which states $\mathrm{BOPO}$ has a negative and significant effect on ROA. Be accepted.

Loan to Deposit Ratio (LDR)

Based on Test $t$ got the coefficient effect of -0.507101 with the level of significance of LDR variable to ROA is 0.6126 with significance level $(\mathrm{sig})=0.6126>0.05$. It shows that LDR variable has negative effect and not significant to ROA. So, hypothesis $2 \mathrm{~b}$. that states LDR has positive and significant effect on ROA. Rejected.

Non-Performing Loan (NPL)

Based on t-test found the coefficient effect of -4.484053 with the level of significance of NPL variable to ROA is 0,000 with a significance level $(\mathrm{sig})=0,000<0.05$. This shows that 
the NPL variable has an effect on ROA. Thus, hypothesis 2c. which states NPL has a negative and significant effect on ROA. Be accepted.

Third party funds (DPK)

Based on Test $t$ obtained the coefficient effect of 1.050514 with the level of significance of DPK to ROA variable is 0.2946 with a significance level $(\mathrm{sig})=0.2946>0.05$. This shows that the DPK variable has a positive and insignificant effect on ROA. Thus, the $2 \mathrm{~d}$. the hypothesis which states DPK has a positive and significant effect on ROA. Rejected.

BI Rate

Based on Test $t$ obtained by the coefficient effect of 2.800938 with the level of significance of the BI Rate to ROA is 0.0055 with a significance level (sig) $=0.0055<0.05$. This shows that the variable BI Rate have a negative and insignificant effect on ROA. Thus, the 2e. hypothesis that the BI rates has a positive and significant effect on ROA. Rejected.

Inflation

Based on Test $t$ got the coefficient effect of -0.654605 with the level of significance of Inflation variable to ROA is 0,5134 with significance level $(\mathrm{sig})=0,5134>0,05$. This shows that the Inflation variable has a negative and insignificant effect on ROA. So, hypothesis $2 \mathrm{f}$. that states Inflation has a positive and significant effect on ROA. Rejected.

\section{Exchange rate}

Based on Test $t$ got the coefficient effect of -0.654605 with the significance level of the exchange rate to ROA is 0.5134 with a significance level $(\mathrm{sig})=0,5134>0,05$. It is shown that the exchange rate variable has a negative effect and not significant to ROA. Thus, the $2 \mathrm{~g}$. the hypothesis which states Exchange rate has a positive and significant effect on ROA. Rejected.

Based on the coefficient value in regression analysis conventional bank obtained $\mathrm{R}$ Square value influence BOPO, LDR, NPL. DPK Birate, Inflation and Exchange Rate to ROA of $47.20 \%$ showing the contribution of BOPO, LDR, NPL. DPK Birate, Inflation and Exchange Rate to ROA.

Selection of Dominant Variables

Based on the results of conventional sharia banks and conventional commercial banks above, it can be seen in sharia commercial banks variables that have an influence on ROA (return on asset) that is BOPO variable with coefficient values of 22.81130 from internal factors and BI rate variable with a coefficient value of 1.261954 from External factors. While in conventional commercial banks variables that influence on ROA is BOPO variable with coefficient values of 15.02173 and NPL with coefficient value of 4.484053 from internal factors and Birate variable with coefficient of 0.654605 from external factors. Therefore, the more dominant variable on ROA (return on asset) in sharia commercial banks and conventional commercial bank is BOPO variable with the highest coefficient value respectively 22.81130 for sharia commercial bank and 15,02173 for the conventional commercial bank.

\section{Conclusion}

Based on the analysis that has been described on the analysis of the influence of internal factors and external factors on sharia commercial banks and conventional commercial banks in Indonesia. The independent variables used are operational income operating expense (BOPO), loan to deposit ratios (LDR), non performing loan (NPL), thirdparty funds (DPK), BI Rate, Inflation and Exchange Rate to profitability level which is proxie 
on return on asset (ROA) at Sharia Commercial Bank and Conventional Commercial Bank in Indonesia with period of first quarter 2009 - until the fourth quarter of 2014. It can be concluded as follows:

1. In sharia bank, internal variable factors that is BOPO partially influences to profitability or ROA (return on assets), while external factor variables that are BI Rate partially influence to profitability or ROA (return on assets).

2. In conventional commercial banks, internal factor variables BOPO and NPL partially affect the profitability or ROA (return on assets), while the external factor variable is the BI Rate partially affect the profitability or ROA (return on assets).

3. In sharia and conventional banks, the internal and simultaneous factors simultaneously have a significant effect on profitability or ROA (return on assets).

4. Variable that more dominant influence on internal factors and external factor to profitability level or ROA (return on assets) of sharia commercial bank and the conventional bank is BOPO variable.

\section{Recommendation}

Based on existing limitations, for subsequent research can use data on a monthly basis with a longer study period, the number of samples added, and other variables that can be used (plus) more so that the results can reflect the effect on the ROA, so that it can be informed to the customer about the size of profitability (ROA) in assessing how much a bank can generate profit or how much the level of income a bank of assets used and can provide a good reference for banks in determining the strategy (election policy) in order to increase the growth of sharia commercial banks and conventional commercial banks in the future.

\section{References}

Christiano, M., Saerang, I., \& Parengkuan, T. (2014). Analysis of Financial Ratios for Measuring Profitability at Private Banks Go Public in Indonesia Stock Exchange. (Online). Sam Ratulangi University Manado Faculty of Economics and Business $\begin{array}{lllll}\text { Program } & \text { S1, } & 2 & (4), & 817-\end{array}$ (http://ejournal.unsrat.ac.id/index.php/emba/article/viewFile/6490/6016, accessed March 8, 2015).

Eprima Dewi, L., Trisna Herawati, N. S., \& Sulindawati, G. E. (2015). Analysis of the Influence of NIM, BOPO, LDR, and NPL on Profitability (Case Study at Private National Private Banks Listed on Indonesia Stock Exchange Period 2009-2013). (Online) Ganesha Education University Accounting Department Program S1, 3 (1). Http://ejournal.undiksha.ac.id/index.php/S1ak/article/viewFile/4752/3603. Accessed March 8, 2015).

Gitman, Laurence J \& Zutter, Chad J. (2012). Principles of Managerial Finance (3rd ed.). Boston: Prentice Hall.

Hendrayanti, S., \& Muharam, H. (2013). Influence Analysis of Internal and External Factors on Banking Profitability (Studies at Commercial Banks in Indonesia Period January 2003 - February 2012). (on line). Diponegoro University Faculty of Economics and Business Program S1, 2, 1-15. (Http://download.portalgaruda.org/article.php?article $=121185 \&$ val $=4727 \quad$ accessed March 8, 2015).

Iqbal, Anjum. (2012). "Liquidity Risk Management: A Comparative Study Between Conventional and Islamic Bank of Pakistan". Global Journal of Management and Business Research, Vol.12, No. 5, 54-64 
Kasmir. (2007). Manajemen Perbankan. Jakarta: PT. RajaGrafindo Persada.

LPPS. (2013). Laporan Perkembangan Perbankan Syariah 2012, www.bi.go.id/id/publikasi/...e62979903c40404095ba3c224baef8b3LPS_2013.pdf. 29 April 2013

Luciana Spica, Almilia \& Anton Wahyu Utomo. (2006). Jurnal Ekonomi dan Bisnis ANTISIPASI Vol. 10(1), 1-27

Purwoko, D., \& Sudiyatno, B. (2013). Factors influencing bank performance (empirical study on banking industry in Indonesia stock exchange). University Stikubank Semarang, $20(1), 25-39$.

Wibowo, Edhi S \& Syaichu, M. (2013). Influence Analysis of Interest Rate, Inflation, CAR, BOPO, NPF on Profitability of Sharia Bank. Diponegoro Journal Of Management, Vol.2 (.2), 1-10. s1.undip.ac.id/index.php/djom/article/view/2651/2643, accessed March 11, 2015)

Widarjono, Agus. (2013). Econometrics Introduction and Its Application. Yogyakarta: UPP STIM YKPN. 